
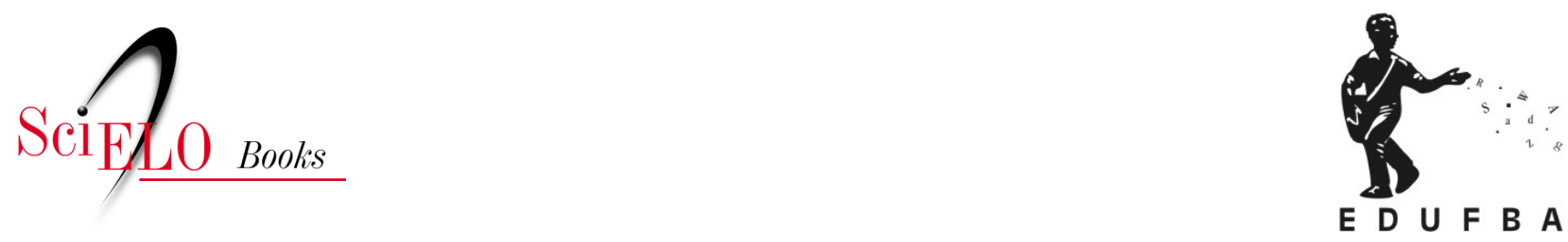

\title{
Epílogo
}

\section{Edward MacRae}

\section{SciELO Books / SciELO Livros / SciELO Libros}

MACRAE, E. Epílogo. In: A construção da igualdade-política e identidade homossexual no Brasil da "abertura" [online]. Salvador: EDUFBA, 2018, pp. 367-369. ISBN 978-85-232-1998-7. https://doi.org/10.7476/9788523219987.0019.

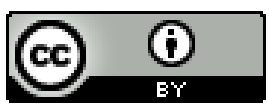

All the contents of this work, except where otherwise noted, is licensed under a Creative Commons Attribution 4.0 International license.

Todo o conteúdo deste trabalho, exceto quando houver ressalva, é publicado sob a licença Creative Commons Atribição 4.0. 


\section{Epílogo}

Talvez, ao chegar aqui, o leitor queira perguntar por que este trabalho é tão longo e detalhista. Em resposta, eu chamaria a atenção para a complexidade da tarefa a que me propus, procurando, por um lado, entender as transformações que ocorrem na construção social da homossexualidade no Brasil e, por outro, lidar com um movimento social inserido em uma conjuntura política. Além do mais, se procurou simultaneamente fazer uma pesquisa e analisar uma vivência, o que não é fácil.

Relendo este trabalho, já pronto, fico um pouco perturbado com a imagem negativa, do Somos e da militância homossexual em geral, que ele pode acabar transmitindo. Receio que isso seja quase inevitável, quando se procura deixar de lado o que é dito, enfatizando o que de fato ocorre e as várias relações estabelecidas entre o grupo que é objeto da pesquisa e as outras forças socialmente atuantes.

Quanto mais elevados os ideais apregoados por uma organização, mais fácil se torna fazê-la parecer hipócrita. Quando, como aqui, se procura entender relações de dominação e manipulação dentro de um grupo que se diz dedicado ao combate ao poder, inevitavelmente essa é uma consequência. Mas desejo deixar claro que, ao procurar, como antropólogo, "desvendar as máscaras sociais" não estou procurando "desmascarar" os militantes. 
A atuação política é necessariamente diversa da pesquisa antropológica e geralmente requer a formulação de utopias que sirvam como pontos de referência para as tentativas de efetuar mudanças na realidade existente. Submetidos a um crivo rigoroso, científico e antropológico, é provável que nenhuma das instituições mais respeitáveis se mostrassem totalmente coerentes com seus ideais, pensemos, por exemplo, nas igrejas, nos partidos políticos ou na própria universidade. Expostos os seus mecanismos internos, todos podem ser pintados com cores sombrias. Mas, desejar simplesmente erradicá-las seria talvez o equivalente a querer a abolição da realidade e não a sua transformação.

Os ideais da luta contra o poder e contra a dominação de um ser humano por outro são profundamente significativos num momento como o atual, quando o processo do controle das mentes e dos corpos é promovido através de métodos que ora empregam a maior sutileza, ora a violência mais brutal. Foucault já nos mostrou que não se pode pular fora das malhas do poder, mas, dada a polivalência tática dos discursos, creio que, em certas ocasiões, pode-se falar contra o poder, em geral, para atacar algumas de suas configurações específicas.

Não há dúvida de que, em nossa sociedade atual, têm sido negado svários dos direitos de cidadania daqueles indivíduos percebidos como sendo homossexuais, usando-se para isso uma enorme variedade de justificativas, que vão desde a saúde e a moral até a segurança nacional. Contra esse estado de coisas, algumas pessoas procuraram reagir, empregando as linguagens correntes em um dado momento histórico. Se não realizaram a sonhada - e, creio, impossível - abolição do "poder", conseguiram de várias maneiras melhorar a sua condição social.

É inegável a eficácia dos grupos homossexuais em vários sentidos. Talvez, a principal tenha sido a construção de redes de sociabilidade, unindo - e também promovendo - um novo tipo de homossexual que não é dominado por sentimento de culpa e não se considera doente ou anormal. Mesmo depois de cessadas as atividades declaradamente militantes, essas redes têm sobrevivido e, em muitos casos, têm sido cruciais na história de vida de muitos de seus participantes, influindo na sua escolha de moradia, de emprego, de atividades de lazer e de opção política. 
Atualmente, com o trágico surto da Síndrome da Imunodeficiência Adquirida (aids), que vem vitimando principalmente homossexuais, tem sido notada a importância dessas redes e da adoção de uma identidade homossexual para uma melhor gestão da crise. Como diz Michael Pollak ao comentar a situação na França: “A solidão de um homossexual perante a moléstia é tanto maior quando ele havia assumido mal a sua homossexualidade e consequentemente não havia conseguido construir laços de amizades estáveis e duráveis à sua volta”. (POLLAK; SCHILTZ, 1987, p. 100)

Do ponto de vista político e social, a atuação dos militantes homossexuais serviu também para tornar a homossexualidade mais "respeitável" ou legítima e hoje muitas autoridades políticas, médicas ou acadêmicas, sentem-se seguras em fazer declarações de apoio ao estilo de vida homossexual sem maiores constrangimentos. Isso adquire uma importância crucial com o advento da aids, quando, apesar da persistência generalizada de preconceitos anti-homossexuais entre médicos e outros profissionais da saúde, os programas oficiais têm sido obrigados a reconhecer a legitimidade social do comportamento homossexual e a necessidade de se respeitar os direitos de cidadania dos seus praticantes.

São Paulo, setembro de 1989. 